\title{
Long-term reticuloruminal pH dynamics and markers of liver health in early- lactating cows of various parities fed diets differing in grain processing
}

\author{
E. Humer, ${ }^{* 1}$ A. Khol-Parisini, ${ }^{* 1}$ L. Gruber, $\dagger$ J. Gasteiner, $\dagger$ Sh. M. Abdel-Raheem, ${ }^{\star 2}$ and Q. Zebeli ${ }^{* 3}$ \\ *Institute of Animal Nutrition and Functional Plant Compounds, Department for Farm Animals and Veterinary Public Health, Vetmeduni Vienna, \\ Veterinaerplatz 1, 1210 Vienna, Austria \\ †Institute of Livestock Research, Agricultural Research and Education Centre Raumberg-Gumpenstein, Raumberg 38,8952 Irdning, Austria
}

\begin{abstract}
The present study aimed to investigate the long-term effect of feeding barley grain steeped in lactic acid (La) with or without thermal treatment on reticuloruminal $\mathrm{pH}$ dynamics and metabolic activity of the liver in 12 primiparous and 18 multiparous early-lactating dairy cows. All cows were included on d 21 postpartum and sampled until d 90 postpartum. Cows were fed a diet based on differently processed ground barley grain: untreated grain (control diet, $\mathrm{CON}$ ), or grain treated with $1 \%$ La alone for $24 \mathrm{~h}$ before feeding (La), or with an additional oven-heating at $55^{\circ} \mathrm{C}$ for $12 \mathrm{~h}(\mathrm{LaH})$. The reticuloruminal $\mathrm{pH}$ and temperature were measured via indwelling sensors that allowed for continuous (every $10 \mathrm{~min}$ ) and long-term measurement from d 21 to 80 postpartum. Blood samples were taken on d 21, 40, and 90 of lactation and analyzed for liver enzymes aspartate aminotransferase (AST), gamma-glutamyltransferase, and glutamate dehydrogenase, as well as bilirubin, bile acids, and serum amyloid A. Dry matter intake was higher in multiparous cows $(20.7 \pm 0.27 \mathrm{~kg} / \mathrm{d})$ compared with primiparous cows $(18.2 \pm 0.33 \mathrm{~kg} / \mathrm{d})$, but was not affected by dietary treatment. Overall, the relatively short duration $(51 \pm 5 \mathrm{~min} / \mathrm{d})$ of reticuloruminal $\mathrm{pH}<5.8$ suggests low risk of subacute ruminal acidosis throughout the experiment. Results indicated that La treatment of barley, with or without heat, lowered the time duration of $\mathrm{pH}<5.8$ compared with $\mathrm{CON}$, but only in primiparous cows (from $118 \pm 13$ to $46 \pm 11$ and $25 \pm 11 \mathrm{~min} / \mathrm{d}$ for CON, La, and LaH, respectively). In multiparous cows, the opposite effect of feeding the La-treated barley on time duration of $\mathrm{pH}<5.8(11 \pm$ 8 vs. $46 \pm 9$ vs. $57 \pm 9 \mathrm{~min} / \mathrm{d}$ for CON, La, and LaH,
\end{abstract}

Received March 3, 2015

Accepted June 7, 2015.

${ }^{1}$ These authors contributed equally to this paper.

${ }^{2}$ Present address: Department of Animal Nutrition and Clinical Nutrition, Faculty of Veterinary Medicine, Assiut University, Assiut, Egypt.

${ }^{3}$ Corresponding author: Qendrim.Zebeli@vetmeduni.ac.at respectively) was observed. Multiparous cows generally showed higher $\mathrm{pH}$ readings and shorter periods in which the ruminal $\mathrm{pH}$ dropped below the threshold of $\mathrm{pH}$ 5.8. The reticuloruminal temperature was not affected by dietary treatment, whereas parity affected the time duration of reticuloruminal temperature $>39.5^{\circ} \mathrm{C}$, being $60 \pm 19 \mathrm{~min} / \mathrm{d}$ shorter in primiparous cows. The measured activities of the liver enzymes AST, gammaglutamyltransferase, and glutamate dehydrogenase, as well as bilirubin, bile acids, and the acute phase protein serum amyloid A, were not affected by grain feeding. Additionally, only one small effect of parity on investigated serum variables was noticed, showing slightly but significantly higher values of AST in multiparous $(80.5 \pm 1.4 \mathrm{U} / \mathrm{L})$ compared with primiparous cows $(76.0 \pm 1.7 \mathrm{U} / \mathrm{L})$. In conclusion, our results indicate greater risk for primiparous cows to develop subacute ruminal acidosis-like conditions during early lactation than multiparous cows. The study also suggests limited benefits of feeding processed barley grain with La with or without thermal treatment to modulate ruminal tolerance of grain feeding, whereby differing effects in primiparous cows were observed compared with multiparous cows.

Key words: rumen $\mathrm{pH}$, parity, liver health, grain processing, lactic acid

\section{INTRODUCTION}

Inclusion of large amounts of grain in the diet is a common practice in dairy cows during early lactation. This feeding practice is useful to alleviate the energy deficit but also keeps the cows at high risk of developing rumen fermentation disorders such as SARA. Subacute ruminal acidosis is characterized by intermittent and moderate drops of ruminal $\mathrm{pH}$ in response to highly fermentable diets (Plaizier et al., 2008; Zebeli and Metzler-Zebeli, 2012). Because this disorder lacks overt clinical signs, its diagnosis relies mostly on ruminal $\mathrm{pH}$ measurements; however, single-point measurements of rumen $\mathrm{pH}$ are not reliable for predicting the 
risk of SARA compared with measuring the duration of $\mathrm{pH}$ below certain SARA thresholds (Penner et al., 2007), which can be obtained by continuous monitoring of rumen pH (Penner et al., 2007; Klevenhusen et al., 2014). Subacute ruminal acidosis is a prevalent metabolic disorder of cattle, and metabolic stress associated with SARA primarily afflicts the energy and lipid metabolism in different body tissues, most importantly in the liver and the mammary gland (Bionaz et al., 2007; Zebeli and Ametaj, 2009; Chang et al., 2015). A long duration of a low ruminal $\mathrm{pH}$ may result in the activation of the acute phase response (APR), commonly perceived as increased concentrations of acute phase proteins such as serum amyloid A (SAA) in the blood of affected cows (Plaizier et al., 2008).

Dairy cow diets should contain sufficient forages rich in physically effective NDF (peNDF) to prevent SARA (Yang and Beauchemin, 2007; Zebeli et al., 2012). However, during early lactation, diets typically contain lower proportion of forage compared with late-lactation diets due to the energy deficit and the need to alleviate it by highly fermentable, energy-rich diets (Zebeli et al., 2010). One promising approach to prevent SARA without the need to change the diet's forage proportion is to feed cereal grains or cultivars with low ruminal degradability (Silveira et al., 2007a,b; Nasrollahi et al., 2012). Studies conducted by Iqbal et al. (2009, 2012) found, for the first time in cattle, that treating barley grain with lactic acid (La) alleviated the risk of SARA when fed to late-lactation cows. Processing of barley grain with La has also been shown to enhance the content of slowly digestible starch and fibers and to trigger the hydrolysis of phytate $\mathrm{P}$ in more recent studies (Deckardt et al., 2014, 2015; Metzler-Zebeli et al., 2014). An additional thermal processing of barley with 50 to $55^{\circ} \mathrm{C}$ and La showed synergistic effects in terms of starch composition, its microscopic structure, and fiber fractions as well as in the hydrolysis of phytate P (Metzler-Zebeli et al., 2014; Harder et al., 2015a,b). However, less is known about feeding La-treated grains in early-lactating dairy cows. Several events such as the sudden reduction of dietary peNDF and the lack of an adequate adaptation of the rumen to a highly fermentable diet make early-lactating dairy cows more susceptible to SARA (Penner et al., 2007; Zebeli et al., 2008; Bannink et al., 2012). Apart from the stage of lactation, SARA susceptibility may also be influenced by parity, with first production heifers being differently sensible to dietary changes than multiparous cows that have experienced more high-grain diets.

Because of the aforementioned beneficial effects of La and thermal treatments on the carbohydrate fractions of barley such as greater content of slowly digestible starch and fibers, we hypothesized that feeding of treated barley modulates reticuloruminal $\mathrm{pH}$ dynamics in early-lactating dairy cows. Another hypothesis of the study was that the effects of barley processing on reticuloruminal $\mathrm{pH}$ and metabolic activity of the liver are different in primiparous vs. multiparous dairy cows due to their presumably different sensibility against fermentable diets. Therefore, the aim of this study was to evaluate long-term dynamics of reticuloruminal $\mathrm{pH}$ and temperature, and the metabolic activity of the liver in early-lactating primiparous and multiparous dairy cows fed differently processed barley grain.

\section{MATERIALS AND METHODS}

\section{Animals and Experimental Design}

The longitudinal trial was conducted at the Dairy Research Facilities of the Institute of Livestock Research, Agricultural Research and Education Centre Raumberg-Gumpenstein, Austria, from June 2012 to March 2013. A total of 30 (12 primiparous and 18 multiparous) early-lactating cows, including 25 Holstein and 5 Simmental cows, were used. At the beginning of the trial, at d 20 postpartum, Holstein cows weighed $599 \pm 56.4 \mathrm{~kg}$ (mean $\pm \mathrm{SD}$ ) and produced $28.4 \pm 5.7$ $\mathrm{kg}$ milk/d, whereas Simmental cows weighed $708 \pm$ $73.4 \mathrm{~kg}$ and produced on average $25.3 \pm 4.2 \mathrm{~kg}$ milk/d. Cows were blocked by expected calving date, breed and parity and were randomly allocated to 1 of 3 different feeding groups (10 cows in each group) using a longitudinal block-randomized design. The feeding experiment started at d 21 postpartum, and cows were sampled for this study until d 90 postpartum. The 3 experimental diets were alike, except for the processing of the barley, which was ground with a hammer mill (Ultra 110/150, Gruber Machineries, Gaspoltshofen, Austria) at 3-mm screen and fed as such for the untreated control group $(\mathbf{C O N})$, ground and steeped 1:1 (wt/vol) in 1\% L-lactic acid (Brenntag, Vienna, Austria) for $24 \mathrm{~h}$ at room temperature (i.e., La), or ground and steeped in L-lacticacid plus heating at $55^{\circ} \mathrm{C}$ for $12 \mathrm{~h}(\mathbf{L a H})$. Preparation of La solutions and chemical treatment of barley grain has been described previously (Deckardt et al., 2014). The chemical composition of the untreated and treated barley grains is shown in Table 1 .

All diets were formulated to meet the energy and nutrient requirements of dairy cows of $650 \mathrm{~kg}$ of $\mathrm{BW}$, producing $35 \mathrm{~kg}$ milk/d with $4 \%$ fat, and $3.3 \%$ protein (GfE, 2001). Diets were designed to provide (DM basis) $50 \%$ forage ( $15 \%$ meadow hay, $15 \%$ grass silage, $20 \%$ corn silage), and $50 \%$ concentrate $[38.5 \%$ barley grain (CON, $\mathrm{La}$, or $\mathrm{LaH}$ ), and $11.5 \%$ of a protein-mineralvitamin mix (PMV)]. The PMV contained extracted soybean- and rapeseed meal in equal proportions, 
Table 1. Analyzed chemical composition of barley grains untreated $(\mathrm{CON})$, or treated with $1 \%$ lactic acid (La), or with $1 \%$ lactic acid and heat $(\mathrm{LaH})$

\begin{tabular}{lccc}
\hline & \multicolumn{3}{c}{ Barley grain } \\
\cline { 2 - 4 } Item $^{1}$ & CON & La & LaH \\
\hline \% of DM unless stated & & & \\
DM, \% fresh matter & 87.1 & 48.1 & 48.2 \\
OM & 96.7 & 97.3 & 97.4 \\
CP & 13.2 & 11.6 & 11.7 \\
Ether extract & 2.6 & 2.1 & 2.2 \\
aNDFom & 19.6 & 20.3 & 20.7 \\
Starch & 61.1 & 59.3 & 60.7 \\
ME, MJ/kg of DM & 12.1 & 12.7 & 12.6 \\
NE, MJ/kg of DM & 7.52 & 8.01 & 7.89 \\
\hline
\end{tabular}

$\overline{{ }^{1} \text { The contents of } \mathrm{ME} \text { and net } \mathrm{NE}_{\mathrm{L}} \text { of the barley grains were calculated }}$ according to Gruber et al. (2014). aNDFom = amylase-treated NDF determined on an organic matter basis.

limestone, salt, and a commercial mineral-vitamin premix for lactating dairy cows. The analyzed chemical composition of the forages and the PMV is shown in Table 2, and the chemical composition and particle size (PS) distribution of the experimental diets (accounting for different intakes by each group) are shown in Table 3. All cows had free access to water. Cows were fed ad libitum in individual Calan gates, being offered $110 \%$ of the average amount of feed consumed on the 3 preceding days (realized average daily feed refusals of 5 to $10 \%)$. Fresh feed was offered twice a day (0430 and $1600 \mathrm{~h}$ ), whereby the cows received their roughage (hay and grass silage) portion first, followed by their barley allowance and corn silage, subsequently being offered each component again for at least $30 \mathrm{~min}$ or until finished. A computer-regulated feeding station was centrally located in the stable to individually and continuously offer the proportion of PMV.

During the experiment, cows were located in a free stall. All procedures involving animal handling and treatment were in accordance with national regulations for animal use in research and approved by the authority according to $\S 9 \mathrm{ff}$, Law for Animal Experiments (GZ FA10A-78Gu-19/2012-2).

\section{Feed Sampling and Chemical Analyses}

Amounts of feed offered and refused were recorded daily to determine the feed intake of cows by difference. Feed and orts samples were collected weekly. They were mixed and aliquots were used for analyses of nutrient composition and PS distribution. Dry matter was determined after oven drying for $72 \mathrm{~h}$ at $55^{\circ} \mathrm{C}$. The ground samples (1-mm screen) were analyzed for $\mathrm{N}$ using the Kjeldahl method, and ether extract and ash were measured according to the official methods (Naumann and Bassler, 2012). The NDF and ADF were determined using the methods described by Van Soest et al. (1991), with heat-stable $\alpha$-amylase used in the NDF procedure. The starch contents of the barley grains were determined enzymatically according to the analysis procedure [AOAC (2002) Official Method 2002.02; AACC (2002) 101 Method 32-40] provided by the Megazyme Kit (Megazyme International Ireland Ltd. Co., Wicklow, Ireland). Calculation of energy concentration of feedstuffs was based on their crude nutrient composition and in vivo digestibility coefficients of individual ingredients determined with the method described by Gruber et al. (2014). The PS distribution was determined using a Penn State Particle Separator with 3 sieves (Kononoff et al., 2003). Particles retained on each fraction were oven dried at $55^{\circ} \mathrm{C}$. The physical effectiveness factors (pef, i.e., the cumulative proportion of feed DM retained on sieves of the Penn State Particle Separator) were nominated as pef $>8$ and pef $_{>1.18}$, respectively. The physically effective NDF of 2 $\left(\mathbf{p e N D F}_{>8}\right)$ and 3 sieves $(\mathbf{p e N D F} \mathbf{P 1 . 1 8})$ were calculated by multiplying the fraction on pef ${ }_{>8}$ and pef $>1.18$ with the NDF content (Kononoff et al., 2003), respectively.

Table 2. Analyzed chemical composition of forages and protein-mineral-vitamin mix (PMV)

\begin{tabular}{|c|c|c|c|c|}
\hline $\begin{array}{l}\text { Item, }{ }^{1} \% \text { of DM } \\
\text { unless otherwise stated }\end{array}$ & Hay & Corn silage & Grass silage & $\mathrm{PMV}^{2}$ \\
\hline $\mathrm{OM}$ & 88.6 & 95.1 & 86.9 & 84.1 \\
\hline $\mathrm{CP}$ & 13.5 & 6.9 & 13.9 & 39.5 \\
\hline Ether extract & 2.4 & 3.3 & 3.8 & 2.0 \\
\hline aNDFom & 45.0 & 44.9 & 47.1 & 16.7 \\
\hline ADFom & 28.6 & 26.7 & 33.1 & 13.4 \\
\hline $\mathrm{NFC}$ & 27.7 & 40.0 & 22.1 & 25.9 \\
\hline $\mathrm{NE}_{\mathrm{L}}, \mathrm{MJ} / \mathrm{kg}$ of $\mathrm{DM}$ & 5.40 & 6.26 & 5.65 & 6.77 \\
\hline
\end{tabular}


Table 3. Analyzed nutrient composition and particle size distribution of the diets fed to primiparous (Prim) and multiparous (Mult) earlylactating dairy cows from d 21 to 80 pospartum $^{1}$

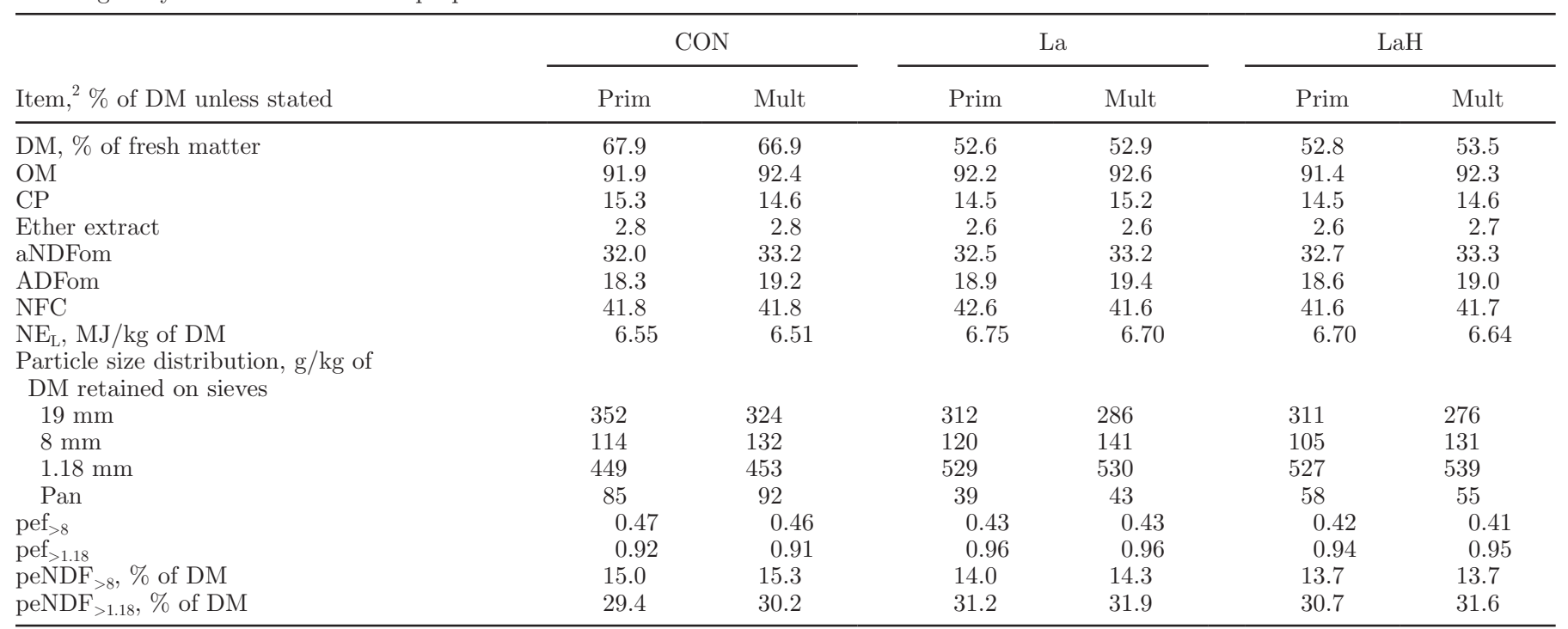

${ }^{1}$ Experimental diets differed in barley grain processing, being either unprocessed (CON), or processed with $1 \%$ lactic acid (La), or with $1 \%$ lactic acid and heat (LaH); Diet components are shown in Table 4.

${ }^{2} \mathrm{NFC}[=100-(\% \mathrm{NDF}+\% \mathrm{CP}+\%$ ether extract $+\%$ ash $)]$ and $\mathrm{NE}_{\mathrm{L}}$ according to (Gruber et al., 2014); aNDFom $=$ amylase-treated NDF determined on an organic matter basis; $\mathrm{ADFom}=\mathrm{ADF}$ determined on an organic matter basis; pef $=$ physically effective factor; peNDF $=$ physically effective NDF (Kononoff et al., 2003).

\section{Reticuloruminal $\mathrm{pH}$ and Temperature}

To monitor rumen $\mathrm{pH}$ continuously, all cows received an indwelling wireless pH-transmitting unit (smaXtec Animal Care Sales GmbH, Graz, Austria). These units (3.5 cm i.d., $12 \mathrm{~cm}$ long, and weighing $210 \mathrm{~g}$ ) were manually inserted into the reticulorumen via the esophagus (Gasteiner et al., 2012) in all cows on d 17 postpartum. Prior to this, the units were calibrated by a 2-point calibration using buffers of $\mathrm{pH} 4.0$ and 7.0 following the company's instruction protocol. The units measured $\mathrm{pH}$ and temperature every $10 \mathrm{~min}$ and transmitted the data in real time to a basis station using the ISM band $(433 \mathrm{MHz})$. Antennas installed in the barn and milking parlor picked up the sensor signals. Both data of $\mathrm{pH}$ and temperature were collected using an analog to digital converter and stored in an external memory chip. As the guaranteed working time of the sensors was $60 \mathrm{~d}$, the measurements were taken continuously until d 80 postpartum from each cow. One concern of the indwelling sensors is that they provide data of $\mathrm{pH}$ only in the site they are located, namely in the reticulum as they are located in the reticulum within $24 \mathrm{~h}$ after administration (Gasteiner et al., 2009). The sensors used in this study were recently evaluated and have shown to satisfactorily reflect the $\mathrm{pH}$ of the free rumen liquid (Klevenhusen et al., 2014). Thus, the term reticuloruminal $\mathrm{pH}$ is used here. Daily mean, minimal, and maximal $\mathrm{pH}$ values, standard deviation, and dura- tion during which the $\mathrm{pH}$ was below thresholds of 5.8 and 6.0 were calculated. Furthermore, diurnal changes (measurements throughout $1 \mathrm{~d}$ taken at 10-min intervals) were analyzed separately. Data of temperature were analyzed for diurnal changes. In accordance to the $\mathrm{pH}$ data, daily mean temperature and duration during which temperature was above a threshold of $39.5^{\circ} \mathrm{C}$ were computed and analyzed separately.

\section{Blood Sampling and Analyses}

Blood samples were collected shortly before the morning feeding from the coccygeal vein on experimental $d$ 21 (baseline), 40, and 90. Serum 10-mL evacuated tubes (Vacuette, Greiner Bio-One, Kremsmünster, Austria) were used to collect blood samples. Immediately after collection, blood samples were allowed to clot for 30 min at $25^{\circ} \mathrm{C}$; subsequently serum was separated by centrifuging at $3,000 \times g$ at $4^{\circ} \mathrm{C}$ for $20 \mathrm{~min}$. Serum samples were stored at $-20^{\circ} \mathrm{C}$ until analyses. Concentrations of SAA were determined by a commercially available ELISA bovine kit according to the method described previously (Klevenhusen et al., 2013). In brief, serum samples for SAA were initially diluted 1:200, and samples with optical density values above the range of the standard curve were diluted further (1:400 or 1:250) and reanalyzed. All samples were tested in duplicate and the optical density values were read by an iMark microplate absorbance reader (Bio-Rad Laboratories 
GmbH, Vienna, Austria) at $450 \mathrm{~nm}$. The concentrations of bile acids, bilirubin, and liver enzymes such as aspartate aminotransferase (AST), glutamate dehydrogenase (GLDH), and gamma-glutamyltransferase (GGT) in the serum were measured by a conventional large-scale analyzer for clinical chemistry at the laboratory of the Central Clinical Pathology Unit, University of Veterinary Medicine, Vienna. The standard enzymatic colorimetric analyses with a fully automated autoanalyzer for clinical chemistry (Cobas 6000/c501; Roche Diagnostics GmbH, Vienna, Austria) was used. The intraassay variation was controlled by limiting the coefficient of variation to $\leq 10 \%$ for SAA and $<5 \%$ for other blood variables.

\section{Statistical Analyses}

Statistical analyses were performed using PROC MIXED of SAS (version 9.2, SAS Institute Inc., Cary, NC). To evaluate the effect of cow's parity, cows were classified in 2 different lactation groups: primiparous $(\mathrm{n}=12)$ or multiparous $(\mathrm{n}=18)$. The model included the fixed effects of block, diet, parity, sampling time (i.e., day or time of the day at 10-min intervals), as well as the diet $\times$ time and diet $\times$ parity interaction. The baseline measurements were considered as covariate in the model. The data gained from the same cow but at different times were considered as repeated measures in the model with a first-order autoregressive variance-covariance matrix. Comparisons among treatments were evaluated by Tukey's test. Degrees of freedom were estimated with the method of Kenward-Roger. Furthermore, the significance of the overall effect of the La treatment was tested for all variables (orthogonal contrast involving the average of the 2 La-treated groups vs. control). Associations among $\mathrm{pH}$ and temperature measurements were studied by performing a Pearson correlation (PROC CORR of SAS). The significance level was set at $P \leq 0.05$, and a trend was considered up to $0.05<P<0.10$ level.

\section{RESULTS}

\section{Nutrient Composition of Barleys and Diets, and Feed Intake}

The processing of barley with La and LaH resulted in minor changes in the composition of crude nutrients and energy content (Table 1). Treatments with La and LaH slightly reduced ash, starch, and CP contents, but increased amylase-treated NDF determined on an organic matter basis (aNDFom) and $\mathrm{NE}_{\mathrm{L}}$ contents of the treated barleys; however, these differences in nutrient and energy contents were less visible in the consumed diets (Table 3).

Effects of barley feeding on DMI from d 21 to 80 of lactation are shown in Table 4. Total DMI was not affected by barley treatment $(P=0.44)$, whereas primiparous cows consumed less $(P<0.01)$ feed $(18.2 \mathrm{~kg}$ of DM/d), including barley grain $(P<0.01)$, compared with their multiparous counterparts $(20.7 \mathrm{~kg}$ of DM/d). Relative intake of the different dietary ingredients did not differ among feeding groups either (Table 4). However, primiparous cows consumed a higher $(P=0.03)$ proportion of barley $(38.8 \%)$ compared with multiparous cows $(36.5 \%)$, and this happened at the expense of hay ( $14.7 \%$ in primiparous cows compared with $16.0 \%$ in multiparous cows, Table 4).

\section{Reticuloruminal $\mathrm{pH}$ and Temperature Changes}

Effects of barley feeding on the reticuloruminal $\mathrm{pH}$ and temperature changes from d 21 to $\mathrm{d} 80$ of lactation are shown in Table 5. In cows receiving LaH barley, the mean, maximum, and minimum reticuloruminal $\mathrm{pH}$ values were lowered by 0.05 units compared with CON and La $(P<0.01)$. Figure 1a shows daily mean $\mathrm{pH}$ values of the 3 dietary treatment groups. Slightly lower $\mathrm{pH}$-values were measured in $\mathrm{LaH}$ cows $(P<$ 0.01 ), whereas no differences between lactation days were observed $(P=0.71)$. As shown in Figure $1 \mathrm{~b}$, mean reticuloruminal temperature was $0.07^{\circ} \mathrm{C}$ higher in La cows compared with $\mathrm{CON}$ and $\mathrm{LaH}(P<0.01)$, whereas no effect of lactation day was recorded $(P=$ $0.65)$. Diurnal variations of mean reticuloruminal $\mathrm{pH}$ as well as temperature on 2 exemplary days (d 40 and 60) are shown in Figure 2. Values were averaged over all treatment groups as no effect of the barley processing method was observed. However, reticuloruminal $\mathrm{pH}$ as well as temperature were affected by time $(P<0.01)$. The $\mathrm{pH}$ profile showed that the $\mathrm{pH}$ maximum occurred just before the offering of fresh feed and declined until 6 to $7 \mathrm{~h}$ thereafter. Additionally, abrupt drops in temperature were noticed when fresh feed was offered. The same was true for water intake, when observing temperature curves of single cows (data not shown). The duration of $\mathrm{pH}$ below the threshold of 6.0 was not influenced by barley treatment and averaged 231 $\mathrm{min} / \mathrm{d}$ (Table 5). In contrast, the daily period of $\mathrm{pH}$ values $<5.8$ was 21 min shorter $(P=0.02$, Figure $3 \mathrm{a})$ in the La groups. The time of $\mathrm{pH}$ below both thresholds was not different between lactation days $(P>0.10)$, whereas time below 5.8 was interactively affected by lactation day and treatment $(P=0.03)$. Interestingly, an interaction between parity and treatment group was observed for the minimum $\mathrm{pH}$, showing the lowest 


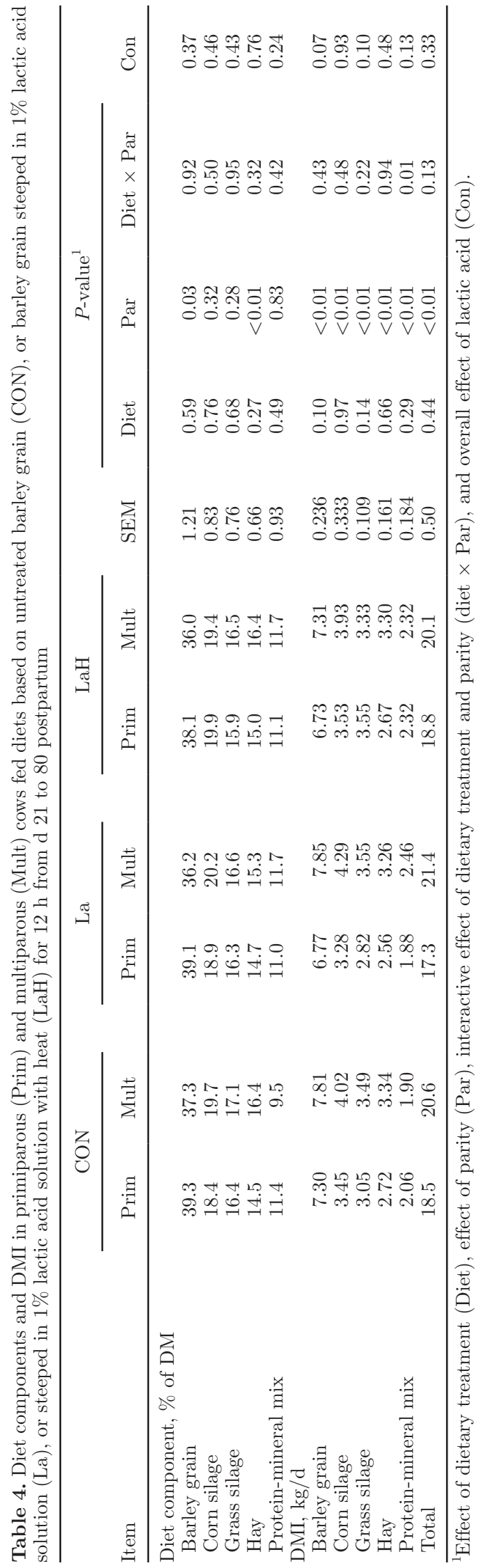

values in primiparous cows of the CON group $(P<$ 0.01 ), resulting in the longest duration of $\mathrm{pH}<6.0$ and 5.8 in these cows $(P<0.01)$. Finally, in primiparous CON cows the duration of the reticuloruminal $\mathrm{pH}<5.8$ was on average $83 \mathrm{~min} / \mathrm{d}$ longer when compared with the 2 other treatment groups (Table $5, P<0.01$ ). On the contrary, in multiparous cows the opposite effect was observed, showing on average a $41 \mathrm{~min} / \mathrm{d}$ shorter duration of reticuloruminal $\mathrm{pH}<5.8$ in $\mathrm{CON}$ cows compared with the cows of the 2 other treatments $(P$ $<0.01)$. Time duration of temperature $>39.5^{\circ} \mathrm{C}$ was neither affected by barley treatment $(P=0.31)$ nor by lactation day $(P=0.27$, Figure $3 \mathrm{~b})$. However, an interaction was observed between lactation day and treatment $(P=0.04)$.

Parity affected certain $\mathrm{pH}$ and temperature variables. Although the mean $\mathrm{pH}$ was not affected (Figure 4a), the maximum $\mathrm{pH}$ was higher in multiparous cows compared with first-lactation heifers $(P<0.01)$. The duration of $\mathrm{pH}<6.0$ was on average $66 \mathrm{~min} / \mathrm{d}$ shorter in multiparous cows $(P=0.02)$. Additionally, the time during which $\mathrm{pH}$ was below the threshold of 5.8 was reduced by $25 \mathrm{~min} / \mathrm{d}$ in cows in second or higher lactation $(P$ $<0.01$, Figure 5a). Mean reticuloruminal temperature was $0.06^{\circ} \mathrm{C}$ higher in multiparous cows compared with primiparous cows $(P<0.01$, Figure $4 \mathrm{~b})$. Furthermore, the time during which temperature was $>39.5^{\circ} \mathrm{C}$ was on average $60 \mathrm{~min} / \mathrm{d}$ longer in multiparous cows compared with first-lactation heifers $(P<0.01$, Figure $5 \mathrm{~b})$.

\section{Serum Variables}

Barley treatment and parity showed minor effects on liver-associated variables (Table 6). No effect of the barley processing technique was observed. Moreover, only small effects of parity on investigated serum variables were noticed. Aspartate aminotransferase showed $6 \%$ higher values in cows in the second or higher lactation compared with primiparous cows $(P=0.05)$. Concentrations of bilirubin decreased with sampling day $(P<$ 0.01 ), whereas none of the investigated serum variables was interactively affected by sampling day and diet.

\section{DISCUSSION}

This study was primarily undertaken to monitor long-term reticuloruminal $\mathrm{pH}$ dynamics and metabolic activity of the liver in early-lactating primiparous and multiparous dairy cows fed a diet based on barley grain processed with La, with or without thermal treatment. All cows were included on d 21 postpartum and sampled until d 90 postpartum, whereby $\mathrm{pH}$ and temperature data were analyzed from d 21 to d 80 postpartum as 
the indwelling sensors allowed for measurement for as many as $60 \mathrm{~d}$.

Depression of ruminal $\mathrm{pH}$ occurs early postpartum due mainly to dramatic dietary changes, whereby SARA is considered a prevalent metabolic disorder during this period (Plaizier et al., 2008). The durations of $\mathrm{pH}$ below thresholds of 5.6 or 5.8 for longer than 3 or $5.4 \mathrm{~h} / \mathrm{d}$, respectively, are considered as safer indicators of SARA than single measurements of $\mathrm{pH}$ (Penner et al., 2007; Plaizier et al., 2008; Zebeli and Metzler-Zebeli, 2012). Overall, the short duration (average time: $51 \mathrm{~min} / \mathrm{d}$ ) of reticuloruminal $\mathrm{pH}<5.8$ suggests a low risk of SARA in the cows of this study. Despite the fact that cows were in early lactation and fed almost $50 \%$ concentrate in the diet, this could be explained by low DMI and a relatively high concentration of peNDF $(>1.18)$ in all diets, averaging $30.8 \%$, which is assumed to be sufficient in maintaining a mean ruminal $\mathrm{pH}$ of above 6 (Zebeli et al., 2008).

Overall results showed limited effects of feeding barley processed with Laor $\mathrm{LaH}$ on reticuloruminal $\mathrm{pH}$. Accordingly, the differences of $0.05 \mathrm{pH}$ units between $\mathrm{LaH}$ compared with $\mathrm{CON}$ and $\mathrm{La}$ is in fact below the $\mathrm{pH}$ accuracy level ( \pm 0.2 units). However, data revealed important differences when analyzed separately by parity. Indeed, an interesting finding of the study was that $\mathrm{La}$ and $\mathrm{LaH}$ treatments of barley shortened the time duration of $\mathrm{pH}<5.8$ by $83 \mathrm{~min} / \mathrm{d}$ in primiparous cows compared with their CON counterparts. This result confirms, at least in part, findings reported by Iqbal et al. (2009), who also observed a slightly shorter duration in which rumen $\mathrm{pH}$ was $<5.8(2.4$ vs. $3.9 \mathrm{~h} / \mathrm{d})$ in primiparous late-lactating cows fed barley steeped in $0.5 \%$ La compared with cows fed control barley grain. The reason(s) why this grain treatment improved the ruminal tolerance of barley in primiparous cows by shortening their time duration of rumen $\mathrm{pH}<5.8$ compared with control cows, but not in multiparous cows, is not clear. Nevertheless, these results suggest that primiparous cows may benefit from La treatments. It is also possible that primiparous cows had a greater SARA challenge than multiparous cows, as evidenced by a longer duration of $\mathrm{pH}<5.8$ in those cows. The processing of barley with La and LaH resulted in few changes in the composition of crude nutrients such as reduced ash, total starch, and $\mathrm{CP}$ contents, and also increased the aNDFom content of the treated barleys, although these chemical changes of barleys were leveled up in the whole diets, which provided almost similar crude nutrient composition to the cows. Most importantly, treatments of barley grain with $\mathrm{La}$ and $\mathrm{LaH}$ have been shown to reduce the rate of enzymatic starch digestion, alter its microscopic structure (Deckardt et al., 2014; Harder et al., 2015a,b), and also modulate 

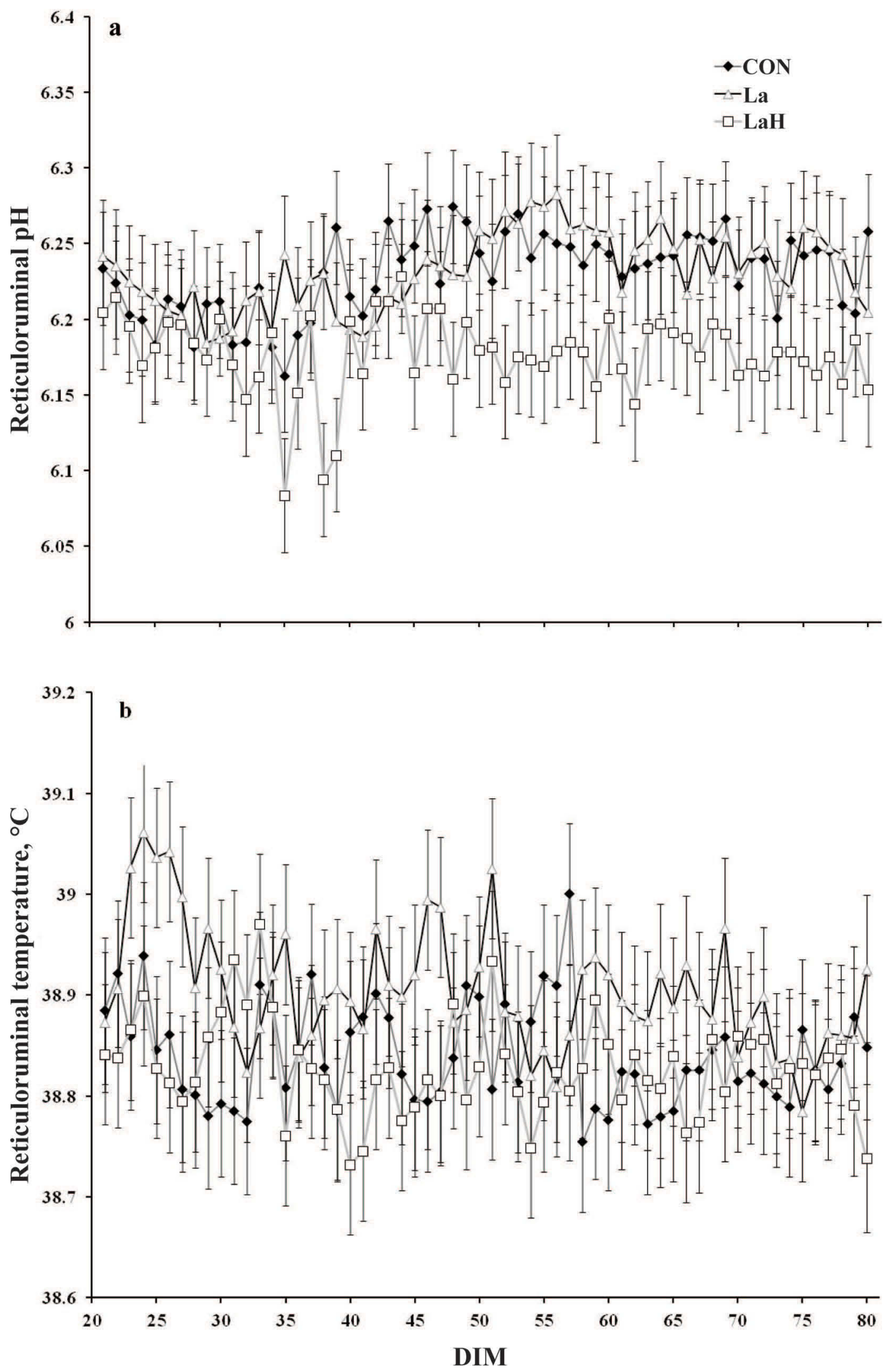

Figure 1. Effect of dietary treatment on mean reticuloruminal $\mathrm{pH}$ (a) and temperature (b) in lactating cows fed barley (CON), barley steeped in $1 \%$ lactic acid solution (La), or steeped in $1 \%$ lactic acid solution with heat (LaH). Error bars represent SEM. 

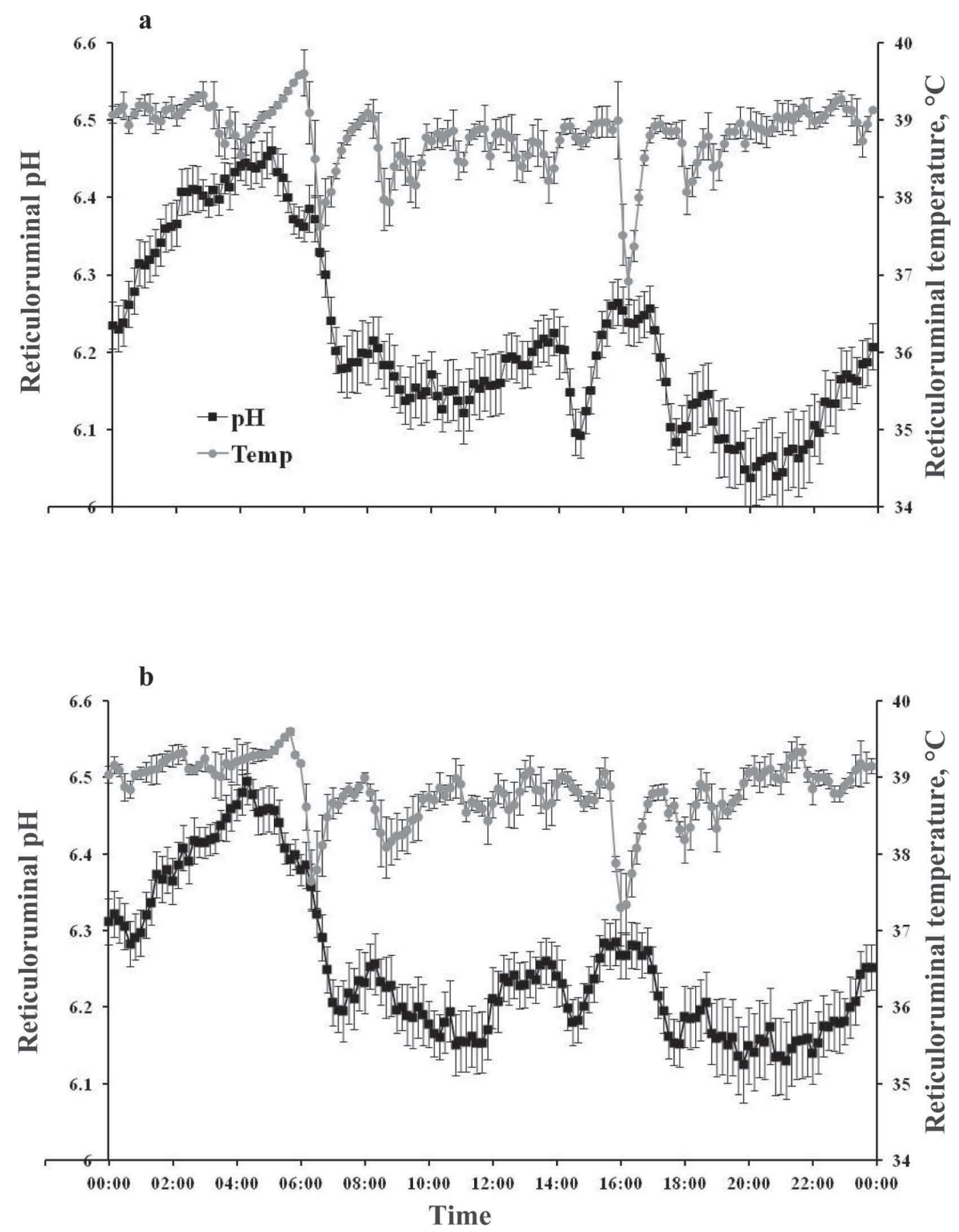

Figure 2. Diurnal variation of reticuloruminal $\mathrm{pH}$ and temperature in lactating cows, averaged across all treatment groups on $\mathrm{d} 40$ (a) and d 60 (b) of lactation. Error bars represent SEM.

rumen microbial activity, and lower the concentration of VFA in a semi-continuous culture fed $60 \%$ concentrate (Deckardt et al., 2015). Grain processing might be more effective in modulating ruminal $\mathrm{pH}$ when cows are fed grain-rich diets, challenging them to SARA conditions. Healthy cows are assumed to be less responsive to dietary treatments compared with SARA-challenged cows, an argument that is further strengthened by the observed interaction between parity and treatment in this study. Evaluation of this hypothesis requires more research with cows fed diets richer in grain. However, it has to be emphasized that the opposite effect to that 

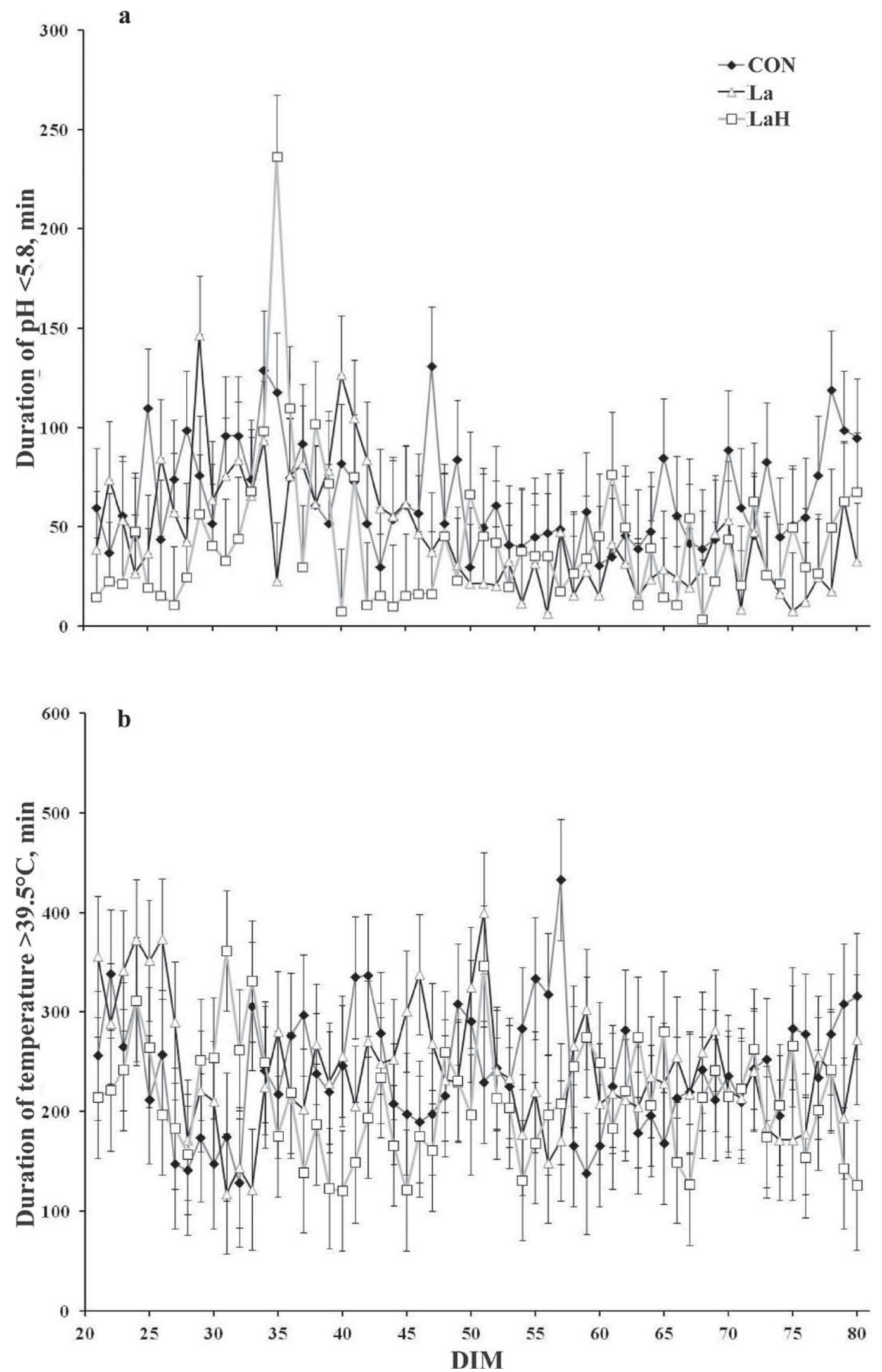

Figure 3. Effect of dietary treatment on time reticuloruminal $\mathrm{pH}<5.8$ (a) and temperature $>39.5^{\circ} \mathrm{C}$ (b) in lactating cows fed barley $(\mathrm{CON})$, barley steeped in 1\% lactic acid solution (La), or steeped in 1\% lactic acid solution with heat (LaH). Error bars represent SEM. 

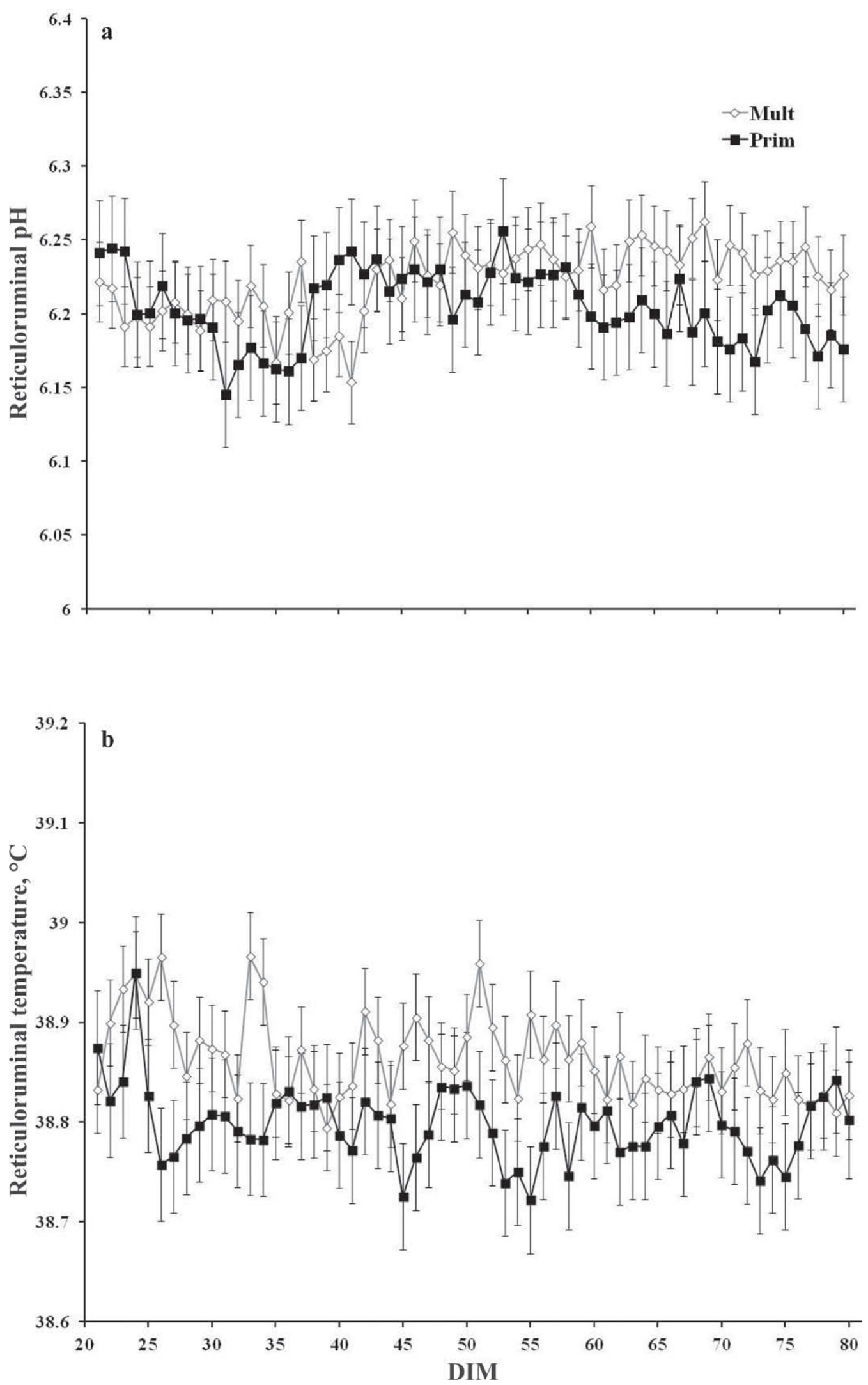

Figure 4. Effect of parity (Mult $=$ multiparous, Prim $=$ primiparous) on reticuloruminal $\mathrm{pH}(\mathrm{a})$ and temperature (b) in lactating cows. Error bars represent SEM. 

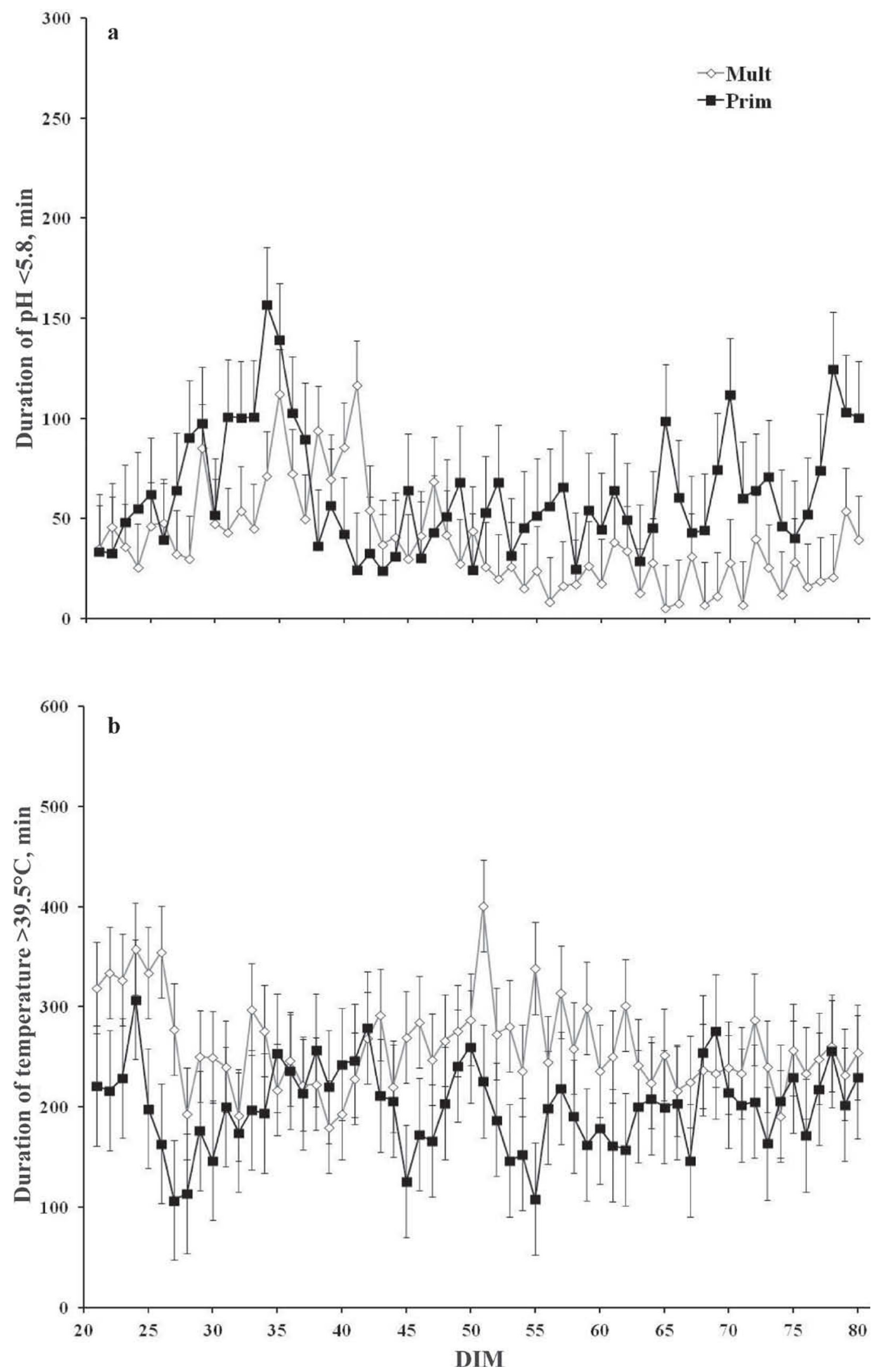

Figure 5. Effect of parity (Mult $=$ multiparous, Prim $=$ primiparous) on time duration of reticuloruminal $\mathrm{pH}<5.8$ (a) and temperature $>$ $39.5^{\circ} \mathrm{C}$ (b) in lactating cows. Error bars represent SEM. 
found for primiparous was observed in multiparous cows, whereby La and LaH cows showed an on average $41 \mathrm{~min} / \mathrm{d}$ longer duration of $\mathrm{pH}<5.8$ compared with the CON group. This contradictory observation of grain processing in primiparous versus multiparous cows is difficult to explain with the current data of $\mathrm{pH}$ dynamics. Clarification of the mechanisms behind the latter effects requires further investigations aiming to establish the effects of barley processing on reticuloruminal fermentation profile such as the dynamics of release, neutralization, and metabolism of VFA and lactate, and also chewing activity, events which are known as determinants of intra-reticuloruminal $\mathrm{pH}$ regulation (Allen, 1997; Zebeli et al., 2012).

Besides monitoring the effect of La-treated barley on $\mathrm{pH}$ dynamics, this study further aimed at investigating possible differences between first-production heifers and multiparous cows. The role of the parity in the risk of developing SARA has not been clarified yet. For example, Krause and Oetzel (2006) and Bramley et al. (2008) observed a decreased risk of developing SARA in multiparous cows compared with primiparous cows, but other studies have reported an opposite trend (Maekawa et al., 2002), or no relation between risk of ruminal acidosis and parity (Gröhn and Bruss, 1990). Generally, one could expect that primiparous cows should be at lower risk of SARA, due to their lower production potential and DMI (Krause and Oetzel, 2006). Indeed, primiparous cows consumed approximately 2.5 $\mathrm{kg} / \mathrm{d}$ less feed DM than multiparous cows in this study. Although multiparous cows had on average 2\% less barley grain at the expense of more hay and corn silage in their diets, these cows in general consumed significantly greater amounts of easily fermentable substrates (14.0 vs. $12.4 \mathrm{~kg}$ of $\mathrm{DM} / \mathrm{d}$ ), contained in concentrates and corn silage, with almost unchanged peNDF 1.18 contents. Because of these feeding patterns, a greater risk of SARA for multiparous cows was expected. It is known that for each unit increase in the DMI, and hence in fermentable substrates and fiber, acid generation rather than acid neutralization processes are stimulated in the rumen of dairy cows (Allen, 1997). However, contrary observations were made in the present study. Multiparous cows showed shorter periods in which $\mathrm{pH}$ decreased below 6.0 and 5.8, respectively. The occurrence of SARA may be exacerbated in firstproduction heifers when compared with multiparous cows, because primiparous cows have not had previous long-term exposure to a highly fermentable lactation diet yet. One possible explanation might be that they may have fewer rumen papillae and less bacterial adaption than mature cows (Penner et al., 2007; Bramley et al., 2008). This is probably the reason why feeding additional concentrate prepartum is suggested to al- 
leviate the risk of postpartum SARA in cows aiming to help them in increasing the absorptive capacity of rumen papilla and adapt better to high grain feeding postpartum (Stone, 2004). However, this was not supported by Penner et al. (2007), who were not able to detect ameliorative effects of feeding additional concentrate in primiparous cows on postpartum SARA development. Another reason for the differing SARA susceptibility might be related to higher chewing time in multiparous cows compared with primiparous cows. Thus, a lower daily saliva output in heifers compared with multiparous cows may result in reduced rumen buffering and consequently in lower $\mathrm{pH}$ compared with older cows (Maekawa et al., 2002; Bowman et al., 2003). Furthermore, Oetzel (2007) assumed that heifers need more time to self-regulate their own ruminal $\mathrm{pH}$ after they start consuming large amounts of cereal grains after parturition compared with multiparous cows. Additionally, first-lactation cows represent a largely unculled population. Thus, it is also possible that the heifers that are unable to learn to self-regulate their own ruminal $\mathrm{pH}$ have not yet been removed from the herd, but will be removed in the following lactations due to complications of SARA (Oetzel, 2007).

In addition, parity affected reticuloruminal temperature. Although the differences of the mean reticuloruminal temperature of $+0.06^{\circ} \mathrm{C}$ is below the measurement accuracy $\left( \pm 0.25^{\circ} \mathrm{C}\right)$, older cows spent $1 \mathrm{~h}$ more per day with a reticuloruminal temperature $>39.5^{\circ} \mathrm{C}$, when compared with primiparous animals. Thus, it seems that the obtained longer duration of high reticuloruminal temperature in the present study was less directly associated with a higher risk of SARA, than rather to a higher heat production due to higher fermentation resulting from higher feed intake in multiparous cows. This is supported by the observation that no correlation was found between ruminal temperature and ruminal $\mathrm{pH}$ in this study $(\mathrm{r}=-0.06)$.

The present study also focused on liver-associated variables, as it is well known that metabolic stress associated with low ruminal $\mathrm{pH}$ during early lactation primarily affects liver function (Bionaz et al., 2007). For instance, in cattle affected by SARA, APR is typically expressed as an increase of the acute phase protein SAA (Plaizier et al., 2008; Iqbal et al., 2010). Furthermore, in early-lactation cows, the liver has to adequately adapt to cope with the increased flow of NEFA resulting from excessive lipolysis (Goff and Horst, 1997). In case of an increased lipid deposition in the liver, lesions of the liver tissue can be the consequence, and levels of enzymes that indicate liver injury (AST, GGT, and GLDH) are generally augmented (Bobe et al., 2004).
The measured activities of AST, GGT, and GLDH corresponded with previous reports (Wille et al., 2010; Lee et al., 2012). In general, liver-associated variables were not affected by barley feeding in this study. Because the values of presented enzyme activities were within reference intervals (Wille et al., 2010), no clear sign is found of impaired liver function of the present cows, which is also explained by low level of SARA and the cows' low production level. Thus, the present data suggest that the process of lipomobilization in these cows was not affected by diet, and was not strong enough to cause liver lesions in early-lactating cows. Although treatment with La and LaH enhanced energy content of barleys by almost 0.4 to $0.5 \mathrm{MJ} / \mathrm{kg}$ of $\mathrm{DM}$, compared with CON barley, the total $\mathrm{NE}_{\mathrm{L}}$ contents of the ingested diets were almost similar. The increase of $\mathrm{NE}_{\mathrm{L}}$ content of La-treated barleys can be mainly explained by changes in the profile of degradation of its nutrients such as ash, CP, starch, phytate $\mathrm{P}$, and soluble fiber (Deckardt et al., 2014; Metzler-Zebeli et al., 2014; Harder et al., 2015a). Also, the addition of $1 \%$ $\mathrm{La}$ in the soaking solution (resulting in $10 \mathrm{~g}$ of $\mathrm{La} / \mathrm{kg}$ of barley) might have contributed to greater energy value of the treated barley. Assuming energy content of 15.1 $\mathrm{kJ}$ per $\mathrm{g}$ of La, the La treatment provided additional 0.15 MJ per each $\mathrm{kg}$ of barley (i.e., $1 \% \mathrm{La}$ solution with ratio 1:1). Because the DMI of concentrate and forages remained unchanged, resulting in no difference in overall DMI among feeding groups, it is reasonable to assume that total $\mathrm{NE}_{\mathrm{L}}$ intake also was similar among treatments. The similar energy intakes together with no SARA conditions likely explain no effect of diets on the process of lipomobilization, APR, and liver health in the cows of our study. Because the intake of barley grain was not significantly affected by treatment, it seems that treatment of grain with $\mathrm{La}$ and $\mathrm{LaH}$ does not negatively affect the palatability of the treated grain.

The concentrations of the acute phase protein SAA were not affected by dietary treatment and generally below recommended cutoff levels for identification of an APR in postparturient dairy cows (Humblet et al., 2006). Thus, the absence of SARA and its related inflammatory state in all treatment groups is further supported. Most liver-associated variables were not affected by parity, too. However, $6 \%$ higher activities of AST were found in multiparous cows compared with primiparous cows. This is supported by Wille et al. (2010) and Cozzi et al. (2011) who found only minor effects of the parity on enzyme activity. In general, elevated levels of certain liver enzymes in multiparous cows compared with primiparous cows could be the 
result of an elevated productive stress compared with primiparous cows.

\section{CONCLUSIONS}

In conclusion, the present study showed contradictory effects of steeping barley grain in La with or without thermal treatment on ruminal tolerance of barley grain feeding, determined by long-term reticuloruminal $\mathrm{pH}$ dynamics; the treatment reduced the duration that reticuloruminal $\mathrm{pH}$ was $<5.8$ in primiparous cows but increased it in multiparous cows. As the risk of SARA seems to be greater in primiparous cows, our data indicate that more care should be taken in the practice in terms of feeding and management of this group of cows. The lack of pronounced effects of dietary treatment on liver-associated variables may be explained by the low production level of the cows and the fact that cows in the present study were not challenged by SARA conditions. Thus, it would be of interest to test the effects of feeding La-treated barley grain on dairy cows challenged with SARA conditions in future studies.

\section{ACKNOWLEDGMENTS}

The contribution of S. Gschaider, A. Rudischer, and A. Dockner (Institute of Animal Nutrition and Functional Plant Compounds at Vetmeduni, Vienna) with their help with the animal trial and the analysis of SAA as well as the staff of the laboratory of the Central Clinical Pathology Unit (Vetmeduni, Vienna) for blood analyses is highly acknowledged. The authors thank the staff of the research station at AREC RaumbergGumpenstein for their care of the cows as well as A. Schauer and A. Adelwöhrer for excellent help in data collection and preparation. This research was supported by a project of the Federal Ministry of Agriculture, Forestry, Environment and Water Management (BMLFUW, Austria, Vienna; project no. 100824), which is highly acknowledged.

\section{REFERENCES}

Allen, M. S. 1997. Relationship between fermentation acid production in the rumen and the requirement for physically effective fiber. J. Dairy Sci. 80:1447-1462.

American Association of Cereal Chemists (AACC). 2002. Resistant Starch in Starch Samples and Plant Materials. AACC Int. 1-7.

AOAC. 2002. Official Method 2002.02 Resistant Starch in Starch and Plant Materials. J. AOAC Int. 85:1103.

Bannink, A., W. J. J. Gerrits, J. France, and J. Dijkstra. 2012. Variation in rumen fermentation and the rumen wall during the transition period in dairy cows. Anim. Feed Sci. Technol. 172:80-94.

Bionaz, M., E. Trevisi, L. Calamari, F. Librandi, A. Ferrari, and G. Bertoni. 2007. Plasma paraoxonase, health, inflammatory conditions, and liver function in transition dairy cows. J. Dairy Sci. 90:1740-1750.
Bobe, G., J. W. Young, and D. C. Beitz. 2004. Invited review: Pathology, etiology, prevention, and treatment of fatty liver in dairy cows. J. Dairy Sci. 87:3105-3124.

Bowman, G. R., K. A. Beauchemin, and J. A. Shelford. 2003. Fibrolytic enyzmes and parity effects on feeding behavior, salivation, and ruminal $\mathrm{pH}$ of lactating dairy cows. J. Dairy Sci. 86:565-575.

Bramley, E., I. J. Lean, W. J. Fulkerson, M. A. Stevenson, A. R Rabiee, and N. D. Costa. 2008. The definition of acidosis in dairy herds predominantly fed on pasture and concentrates. J. Dairy Sci. 91:308-321.

Chang, G., K. Zhang, T. Xu, D. Jin, J. Guo, and S. Zhuang. 2015. Epigenetic mechanisms contribute to the expression of immune related genes in the livers of dairy cows fed a high concentrate diet. PLoS ONE 10:e0123942. http://dx.doi.org/10.1371/journal. pone.0123942.

Cozzi, G., L. Ravarotto, F. Gottardo, A. L. Stefani, B. Contiero, L. Moro, M. Brscic, and P. Dalvit. 2011. Short communication: Reference values for blood parameters in Holstein dairy cows: Effects of parity, stage of lactation, and season of production. J. Dairy Sci. 94:3895-3901.

Deckardt, K., R. Khiaosa-Ard, H. Grausgruber, and Q. Zebeli. 2014. Evaluation of various chemical and thermal feed processing methods for their potential to enhance resistant starch content in barley grain. Starch 66:558-565.

Deckardt, K., B. U. Metzler-Zebeli, and Q. Zebeli. 2015. Processing barley grain with lactic and tannic acid ameliorates rumen microbial fermentation and degradation of dietary fibre in vitro. J. Sci. Food Agric. http://dx.doi.org/10.1002/jsfa.7085.

Gasteiner, J., M. Fallast, S. Rosenkranz, J. Häusler, K. Schneider, and T. Guggenberger. 2009. Measuring rumen $\mathrm{pH}$ and temperature by an indwelling and wireless data transmitting unit and application under different feeding conditions. Wien. Tierarztl. Monatsschr. 96:188-194.

Gasteiner, J., T. Guggenberger, J. Häusler, and A. Steinwidder. 2012. Continuous and long-term measurement of reticuloruminal $\mathrm{pH}$ in grazing dairy cows by an indwelling and wireless data transmitting unit. Vet. Med. Int. 2012:236956.

German Society of Nutrition Physiology (GfE) 2001. Recommendations for the Supply of Energy and Nutrients to Dairy Cows and Heifers. Committee for Requirement Standards of the Society of Nutrition Physiology (in German). DLG-Verlag, Frankfurt am Main, Germany.

Goff, J. P., and R. L. Horst. 1997. Physiological changes at parturition and their relationship to metabolic disorders. J. Dairy Sci. 80:1260-1268.

Gröhn, Y. T., and M. L. Bruss. 1990. Effect of diseases, production, and season on traumatic reticuloperitonitis and ruminal acidosis in dairy cattle. J. Dairy Sci. 73:2355-2363.

Gruber, L., M. Urdl, W. Obritzhauser, A. Schauer, J. Häusler, and B. Steiner. 2014. Influence of energy and nutrient supply pre and post partum on performance of multiparous Simmental, Brown Swiss and Holstein cows in early lactation. Animal 8:58-71.

Harder, H., A. Khol-Parisini, and Q. Zebeli. 2015a. Modulation of resistant starch and nutrient composition of barley grain using organic acids and thermal cycling treatments. Starch 67:654-662. http://dx.doi.org/10.1002/star.201500040.

Harder, H., A. Khol-Parisini, and Q. Zebeli. 2015b. Treatments with organic acids and pullulanase differently affect resistant starch and fiber composition in flour of various barley genotypes (Hordeum vulgare L.). Starch 67:512-520.

Humblet, M. F., H. Guyot, B. Boudry, F. Mbayahi, C. Hanzen, F. Rollin, and J. M. Godeau. 2006. Relationship between haptoglobin, serum amyloid A, and clinical status in a survey of dairy herds during a 6-month period. Vet. Clin. Pathol. 35:188-193.

Iqbal, S., S. J. Terrill, Q. Zebeli, A. Mazzolari, S. M. Dunn, W. Z. Yang, and B. N. Ametaj. 2012. Treating barley grain with lactic acid and heat prevented sub-acute ruminal acidosis and increased milk fat content in dairy cows. Anim. Feed Sci. Technol. 172:141-149.

Iqbal, S., Q. Zebeli, A. Mazzolari, G. Bertoni, S. M. Dunn, W. Z. Yang, and B. N. Ametaj. 2009. Feeding barley grain steeped in 
lactic acid modulates rumen fermentation patterns and increases milk fat content in dairy cows. J. Dairy Sci. 92:6023-6032.

Iqbal, S., Q. Zebeli, A. Mazzolari, S. M. Dunn, and B. N. Ametaj. 2010. Feeding rolled barley grain steeped in lactic acid modulated energy status and innate immunity in dairy cows. J. Dairy Sci. 93:5147-5156.

Klevenhusen, F., M. Hollmann, L. Podstatzky-Lichtenstein, R. Krametter-Frötscher, J. R. Aschenbach, and Q. Zebeli. 2013. Feeding barley grain-rich diets altered electrophysiological properties and permeability of the ruminal wall in a goat model. J. Dairy Sci. 96:2293-2302.

Klevenhusen, F., P. Pourazad, S. U. Wetzels, M. Qumar, M. A. KholParisini, and Q. Zebeli. 2014. Technical note: Evaluation of a realtime wireless $\mathrm{pH}$ measurement system relative to intraruminal differences of digesta in dairy cattle. J. Anim. Sci. 92:5635-5639.

Kononoff, P. J., A. J. Heinrichs, and D. R. Buckmaster. 2003. Modification of the Penn State forage and total mixed ration particle separator and the effects of moisture content on its measurement. J. Dairy Sci. 86:1858-1863.

Krause, K. M., and G. R. Oetzel. 2006. Understanding and preventing subacute ruminal acidosis in dairy herds: A review. Anim. Feed Sci. Technol. 126:215-236.

Lee, H. H., K. Kida, R. Miura, H. Inokuma, A. Miyamoto, C. Kawashima, S. Haneda, Y. I. Miyake, and M. Matsui. 2012. Slow recovery of blood glucose in the insulin tolerance test during the prepartum transition period negatively impacts the nutritional status and reproductive performance postpartum of dairy cows. J. Vet. Med. Sci. 74:457-464.

Maekawa, M., K. A. Beauchemin, and D. A. Christensen. 2002. Chewing activity, saliva production, and ruminal $\mathrm{pH}$ of primiparous and multiparous lactating dairy cows. J. Dairy Sci. 85:1176-1182.

Metzler-Zebeli, B. U., K. Deckardt, M. Schollenberger, M. Rodehutscord, and Q. Zebeli. 2014. Lactic acid and thermal treatments trigger the hydrolysis of Myo-inositol hexakisphosphate and modify the abundance of lower Myo-inositol phosphates in barley (Hordeum vulgare L.). PLoS ONE 9:e101166. http://dx.doi. org/10.1371/journal.pone.0101166.

Nasrollahi, S. M., M. Khorvash, G. R. Ghorbani, A. Teimouri-Yansari, A. Zali, and Q. Zebeli. 2012. Grain source and marginal changes in forage particle size modulate digestive processes and nutrient intake of dairy cows. Animal 6:1237-1245.

Naumann, C., and R. Bassler. 2012. Die chemische Untersuchung von Futtermitteln. VDLUFA Verlag, Darmstadt, Germany.

Oetzel, G. R. 2007. Subacute ruminal acidosis in dairy herds: Physiology, pathophysiology, milk fat responses and nutritional management. Pages 89-119 in Am. Assoc. Bovine Pract. 40th Annual
Conference, Sep. 17. Vancouver, BC, Canada. University of Wisconsin, Madison.

Penner, G. B., K. A. Beauchemin, and T. Mutsvangwa. 2007. Severity of ruminal acidosis in primiparous Holstein cows during the periparturient period. J. Dairy Sci. 90:365-375.

Plaizier, J. C., D. O. Krause, G. N. Gozho, and B. W. McBride. 2008 Subacute ruminal acidosis in dairy cows: The physiological causes, incidence and consequences. Vet. J. 176:21-31.

Silveira, C., M. Oba, K. A. Beauchemin, and J. Helm. 2007a. Effect of grains differing in expected ruminal fermentability on the productivity of lactating dairy cows. J. Dairy Sci. 90:2852-2859.

Silveira, C., M. Oba, W. Z. Yang, and K. A. Beauchemin. 2007b. Selection of barley grain affects ruminal fermentation, starch digestibility, and productivity of lactating dairy cows. J. Dairy Sci. 90:2860-2869.

Stone, W. C. 2004. Nutritional approaches to minimize subacute ruminal acidosis and laminitis in dairy cattle. J. Dairy Sci. 87(E Suppl.):E13-E26.

Van Soest, P. J., J. B. Robertson, and B. A. Lewis. 1991. Methods for dietary fiber, neutral detergent fiber, and nonstarch polysaccharides in relation to animal nutrition. J. Dairy Sci. 74:3583-3597.

Wille, S., A. Simon, M. Platen, and C. Oertel. 2010. Factors influencing the activity of liver enzymes of clinically healthy dairy cows under field conditions. Zuchtungskunde 82:155-164.

Yang, W. Z., and K. A. Beauchemin. 2007. Altering physically effective fiber intake through forage proportion and particle length: Chewing and ruminal pH. J. Dairy Sci. 90:2826-2838.

Zebeli, Q., and B. N. Ametaj. 2009. Relationships between rumen lipopolysaccharide and mediators of inflammatory response with milk fat production and efficiency in dairy cows. J. Dairy Sci. 92:3800-3809

Zebeli, Q., J. R. Aschenbach, M. Tafaj, J. Boguhn, B. N. Ametaj, and W. Drochner. 2012. Invited review: Role of physically effective fiber and estimation of dietary fiber adequacy in high-producing dairy cattle. J. Dairy Sci. 95:1041-1056.

Zebeli, Q.. J. Dijkstra, M. Tafaj, H. Steingass, B. N. Ametaj, and W. Drochner. 2008. Modeling the adequacy of dietary fiber in dairy cows based on the responses of ruminal $\mathrm{pH}$ and milk fat production to composition of the diet. J. Dairy Sci. 91:2046-2066.

Zebeli, Q., D. Mansmann, H. Steingass, and B. N. Ametaj. 2010. Balancing diets for physically effective fibre and ruminally degradable starch: A key to lower the risk of sub-acute rumen acidosis and improve productivity in dairy cattle. Livest. Sci. 127:1-10.

Zebeli, Q., and B. U. Metzler-Zebeli. 2012. Interplay between rumen digestive disorders and diet-induced inflammation in dairy cattle. Res. Vet. Sci. 93:1099-1108. 